\title{
Is it Possible to Think the Research in Childhood from Psychoanalysis?
}

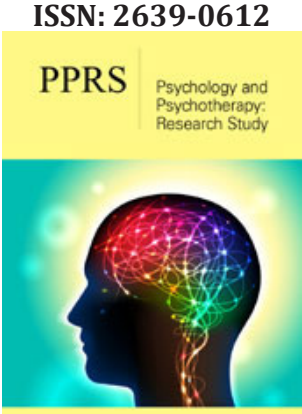

*Corresponding author: Silvina Cohen Imach, Especialización en Psicología Clínica de Niños y Adolescentes, Argentina

Submission: 盟 May 06, 2019

Published: 畺 May 22, 2019

Volume 2 - Issue 3

How to cite this article: Silvina Cohen Imach. Is it Possible to Think the Research in Childhood from Psychoanalysis?. Psychol Psychother Res Stud. 2(3). PPRS.000539.2019.

DOI: 10.31031/PPRS.2019.02.000539

Copyright@ Silvina Cohen Imach, This article is distributed under the terms of the Creative Commons Attribution 4.0 International License, which permits unrestricted use and redistribution provided that the original author and source are credited.

\section{Mini Review}

This paper will attempt to address the intersection between research and psychoanalysis; concepts which in recent years have left of being a bad team. Although the term research has long been discredited within the psychoanalytic areas, at the beginning of the analytic experience, Freud had assigned an essential place. Research involving always encounter with fingerprints, markings, signs, through which you get to the truth of the thing. Involved, although not always made explicit, an epistemology, a plan of research based on the objectives and conditions of inquiry, some techniques that are used to collect the information, and finally, a method of analysis of those data León [1]. Two large prevailing methodological paradigms in science are called quantitative, positivist source methods, and qualitative methods, which involved over the subjectivity of the researcher, of phenomenological/hermeneutical origin. Although my practice as a researcher comes from the hand of investigations called empirical, with a mainly quantitative methodology, although always in the search for the articulation with qualitative data, in this communication I'm going to allow to think, to question, to interrogate the Research from another discipline such as Psychoanalysis, which determines its own methodology of research.

The method created by Freud inaugurates a new form of research, in the intermingling of the clinic, theory and the need for decoding the rhetoric of the unconscious and its praxis language games. Then, think research in childhood from the paradigms of psychoanalysis, supposed to do a cut of our object of study; study that sometimes it can take the forms of disillusionment, due to its complexity, but also bet, as means to resume the Freudian spirit that brings into play in the clinic and the research. Addressing our object of study since this discipline is not easy, because it is the subject of the unconscious, "all your aim, the outer to the inner, material reality to the psychic reality, of the clinical fact to fantasy, and it objectively aware to the subjectively unconscious" Wallerstein [2]. As for case collection technique, is always found, never seek, in spaces which enables our practice; Praxis, offering signs and markings for their interpretation and construction. The strategy of the history or the presentation of a case will be one of forms, used for more than one century, contrast theory and praxis, and when necessary, question the theory up to touch it.

Reviewing its history, recorded that already by the end of the $19^{\text {th }}$ century, Charcot, with the motive for innovation in the practice of Neurology at Salpêtrière Hospital (Paris, France), begins a series of meetings of clinical demonstrations in front of different audiences) Rueda [3]; methodology that Freud revisits, and replicates it in the Vienna Circle those presentations of patients based on their paradigmatic cases. Years later, Jacques Lacan also holds meetings with the sick in the Sainte-Anne Hospital in Paris twice a week. And since 1973, Jacques Allain Miller, performs this activity in Paris Russelle Hospital, in what it called "The circle".

Either written or in the form of "presentation of sick", the presentation of a case aimed at pointing the particularity of the subject, making substantive reference to the singularity. It is based on the method of case study, valuable tool that allows you to investigate the suffering of a subject of in-depth. In accordance with Stake, "the first duty of the case study is to 
understand this case". It must both respect the premise of casuistic understanding, since it is this which allows the generalization and its value as a scientific fact.

It preserves a methodological structure that is based on clinical and technical aspects. The theoretical consistency relies mainly on clinical content, provided by the productions of the child during the process and intervention strategies. The clinical case is as well as a space showing productions of the subject child and her parents; space emerges where what occurs in one by one, based on demand and starting up the transfer Gómez [4]. The material thus finds a systematic organized through different categories of analysis.

In conclusion, it should be noted the nodular resulting to write a case, even with the limitations posed by always being a cutout, recognizing the achievements but also the limits that we impose upon investigating from a clinical case, in an attempt to of showing the truth of the subject, its historical truth and the vicissitudes of a treatment [5].

Research from psychoanalysis is, then, the challenge and the commitment to produce a new level of articulation between three fields that cannot should never switched off. It's a new knotting between theory, practice and clinic, which is nothing other than the consequences of reflecting on our practice. Compare theory and praxis, and when necessary, question the theory up to move it. This is one of the main objectives of the research in psychoanalysis.

\section{References}

1. León O, Montero I (2003) Métodos de investigación en Psicología y Educación. Madrid, McGraw-Hill, Spain, pp. 40-51.

2. Wallerstein I (2004) Las incertidumbres del saber. Barcelona, Gedisa, Spain.

3. Rueda F (2001) 20 años de presentación de enfermos en el scf- Bilbao [en línea], Red de formación continuada, Instituto del campo freudiano, Bilbao, Spain.

4. Gómez P, Pinilla Z, Zapata G (2010) Presentación de caso clínico: herramienta pedagógica para el aprendizaje de la clínica en estudiantes de la Facultad de Psicología de la Universidad Cooperativa de Colombia. Revista de la Facultad de Psicología Universidad Cooperativa de Colombia 6(11): 39-51.

5. Stake R (1995) Investigación con estudio de casos. Morata, Madrid, Spain. 